AGRO EKONOMI, Vol 29, Issue 2, December 2018, Page. 299-309

DOI : http://doi.org/10.22146/ae.36468

ISSN 0215-8787 (print), ISSN 2541-1616 (online)

Available at https://jurnal.ugm.ac.id/jae/

\title{
THE IMPACT OF GAP-SOP ON THE PRODUCTION AND TECHNICAL EFFICIENCY OF GARLIC IN TEMANGGUNG REGENCY
}

\section{Dampak GAP-SOP terhadap Produksi dan Efisiensi Teknis Bawang Putih di Kabupaten Temanggung}

\author{
Aristiyana Nur Tri Wardani ${ }^{1}$, Dwidjono Hadi Darwanto ${ }^{2}$ \\ ${ }^{1}$ Student of Agricultural Economics, Faculty of Agriculture, Universitas Gadjah Mada \\ ${ }^{2}$ Lecturer of Faculty of Agriculture, Universitas Gadjah Mada \\ Jl. Flora, Bulaksumur, Kec. Depok, Kabupaten Sleman, \\ Daerah Istimewa Yogyakarta 55281 \\ aristiyanantw@gmail.com
}

Submitted: 25 June 2018; Revised: 3 November 2018; Accepted: 7 December 2018

\begin{abstract}
Temanggung regency is the largest garlic producer region in Central Java Province. However, its productivity is still low compared to the other regencies since garlic farmers have not achieved technical efficiency and limitary garlic farming technology. Hence, it is necessary to investigate whether the input application in the process of garlic production has been at technically efficient level or not. This research aims to determine factors affecting garlic production, the level of technical efficiency and technical inefficiency of garlic farming in Temanggung Regency. The location of the research was determined by using purposive sampling. The sample selection used simple random sampling method with 60 garlic farmers as the respondent. The result shows that production factors such as land area, garlic seed, ZK fertilizer, pesticide and the level of application of garlic GAP-SOP have significant effect on garlic production. The average value of farmer's technical efficiency is 0,811 . It means that respondents in this study have been technically efficient. The socio-economic factors affecting technical inefficiency are the age, the number of worker in a family, the level of education and participation rate within farmer group. The improvement effort of technical efficiency of garlic farming can be done by optimizing the contribution of farmer group as a facility to access information. Therefore, it is able to improve the skills and knowledge of farmers to farm garlic.
\end{abstract}

Keywords: Garlic, Technical efficiency, Technical inefficiency, Temanggung

Wardani, A.N.T. \& Darwanto, D.H (2018) The Impact of GAP Sop on The Production and Technical Efficiency of Garlic in Temanggung Regency. Agro Ekonomi, 29(2) : 299-309

\section{INTISARI}

Kabupaten Temanggung merupakan daerah penghasil bawang putih terbesar di Provinsi Jawa Tengah. Namun, produktivitasnya masih rendah dibandingkan kabupaten lain, karena petani bawang putih belum mencapai efisiensi teknis dan teknologi pertanian bawang putih yang terbatas. Oleh karenanya, penting untuk menyelidiki apakah aplikasi input dalam 
proses produksi bawang putih telah berada pada tingkat yang efisien secara teknis atau tidak. Penelitian ini bertujuan untuk mengetahui faktor-faktor yang mempengaruhi produksi bawang putih, tingkat efisiensi teknis dan inefisiensi teknis usahatani bawang putih di Kabupaten Temanggung. Lokasi penelitian ditentukan secara purposive sampling. Pemilihan sampel menggunakan metode simple random sampling sebanyak 60 petani bawang putih. Hasil Penelitian menunjukan bahwa faktor produksi seperti lahan, benih bawang putih, pupuk $Z K$, pestisida dan tingkat penerapan GAP-SOP berpengaruh positif dan signifikan terhadap produksi bawang putih. Nilai rata-rata efisinsi teknis adalah 0,811. Hal ini berarti bahwa responden di lokasi penelitian telah efisien secara teknis. Faktor sosial ekonomi yang berpengaruh terhadap inefisiensi teknis adalah usia, jumlah tenaga kerja dalam keluarga, tingkat pendidikan dan keikutsertaan dalam kelompok tani. Upaya perbaikan efisiensi teknis usahatani bawang putih dapat dilakukan dengan mengoptimalkan peran kelompok tani sebagai sarana untuk mengakses informasi. Oleh karena itu, dapat meningkatkan keterampilan dan pengetahuan petani untuk menanam bawang putih.

Kata kunci: Bawang Putih, Efisiensi teknis, Inefisiensi teknis, Temanggung

\section{INTRODUCTION}

Garlic is one of the horticulture commodities which is mostly required by a community as spice, condiment and medicinal plant (Zelelew et al., 2017). Aside from that, it can be used as a herbal medicine. The content of essential oil on garlic is useful as the anti-bacteria and anti-septic, while the allicin and alliin substances generates anti-cholesterol (Falo et al., 2016). Its consumption per capita has been increasing gradually between 2014 and 2016, which were 0.30 ounce, 0.335 ounce and 0.339 ounce respectively. Although it was categorized as low, however, the needs are considered as high in accordance with the national aggregate. From 2014 to 2016, the total anual consumptions of garlic increased by $394,386,446,803$, and 456,614 tons respectively. Nevertheless, the fulfilment of national garlic is still depending on import in which more than $90 \%$ are stocked from China and India (Hariwibowo et al., 2014). This high dependency has impacted the economy stability. In that order, the efforts to improve the production of local variety garlic in fulfilling the national needs and reducing the dependency towards the other countries are required.

Temanggung Regency is the largest producer of garlic in Central Java Province. The production and the area of garlic yields in Temanggung Regency is the biggest compared to the other regencies in Central Java. The productivity of garlic in this regency is 49.9 Quintal/Ha. However, if it is seen from the productivity, it is still categorized as low compared to the other regions, for example in Karanganyar Regency which can produce 104.9 Quintal/ Ha. The General Directorate of Horticulture has released the list of productivities of each garlic variety which are different, in 
which the productivity of (1) lumbu hijau is 11-12 ton per ha, (2) the productivity of new Tawangmangu variety is $10-12$ ton/ ha, (3) the productivity of lumbu kuning variety and sangga sembalun is 9-10 ton per ha. These conditions show that the productivity of garlic in Temanggung Regency is considered as low. Adrianto et al., (2016) mentioned that the low productivity is caused by several factors including the technical efficiency in allocating the production input which has not been able to be reached, the existence of technical inefficiency effect and the limited production of technology influencing the production improvement One of the recommended garlic cultivation technologies is the Good Agricultural Practice - Standard Operating Procedure (GAP-SOP) application. The GAP recommends precise cultivation technology considering environmental aspects of sustainable agriculture. Its application is technically described in a Standard Operating Procedure (SOP) which is specific, based on the location. It is found that the application contributes positively towards farm technical efficiency (Taraka et al., 2011). Banyuriatiga et al., (2017); Ardiansyah et al., (2018) state that factors affecting technical inefficiency positively are age, family member, education level and training/workshop. These factors could increase the level of technical inefficiency. On the other hand, the significant factor affecting technical inefficiency negatively is the experience of farming. It decreases the level of technical inefficiency. The GAP-SOP is a new garlic cultivation technology, which has been introduced since 2016. In other words, garlic farmers in research location have been applied this technology twice. So far, study on the application of garlic GAP-SOP in Temanggung district has never been conducted. Therefore, this study needs to be done to determine the effect of GAP-SOP implementation on production and technical efficiency. Based on this situation, this study aims to determine factors affecting garlic production, the level of technical efficiency and other relevant factors influencing technical inefficiency of garlic farming in Temanggung Regency.

\section{METHODS}

\section{Data and Location}

The research location was determined by purposive sampling consideration certain things. The research was conducted in Kledung District, Temanggung Regency, considering that this area has the biggest production and harvested area of garlic in Temanggung Regency. The respondents consisted of 60 garlic farmers in Kledung District which was determined by random sampling method. The types and sources of data in this research consisted of 2 types, primary and secondary data. The primary data were directly obtained from garlic 
farmers, while the secondary data were obtained from various related institutions. The data collecting method consists of observation and interview with the support of questionnaire. The data used was a primary data of 2018.

\section{Analytical Framework}

\section{The technical efficiency of garlic farming}

The level of technical efficiency can be discovered by using Frontier 4.1 applications. In order to acquire technical efficiency value can be acquired through the formulation as follows.

$$
T E_{i}=\frac{Y}{Y^{*}}=\frac{E\left(Y \mid U_{i} X_{i}\right)}{E\left(Y^{*} \mid U_{i}=0 X_{i}\right)}=E\left[\frac{\exp \left(-U_{i}\right)}{s_{i}}\right] \ldots
$$

Where $\mathrm{TE}_{\mathrm{i}}$ is the farmers' technical efficiency to-i. $\operatorname{Exp}\left[E(-U i) / \varepsilon_{i}\right]$ is the expected value of Ui with terms $\varepsilon_{\mathrm{i}}$. The technical efficiency values are ranged between 0 and 1 , or $0 \leq T E_{i} \leq 1$. If the TE's value is approaching 1 , then the garlic farming can be determined as more efficient, and if the TE's value is approaching 0 , then the garlic farming can be determined as technically inefficient (Coelli et al., 2005). The value of farmers' technical efficiency is categorized quite efficient if it is worth $>0,7$ and categorized yet efficient if worth $\leq 0,7$ (Nainggolan et al., 2017).

The production function of stochastic frontier is used to estimate the maximum production that can be achieved at the application level of the existing production factors as well as observing the technical efficiency level and the factors influencing the technical inefficiency on garlic farming. The formulation of stochastic frontier production function can be formulated as follows.

$\ln Y=\beta_{0}+\beta_{1} \ln X_{1}+\beta_{2} \ln X_{2}+\beta_{3} \ln X_{3}+\beta_{4} \ln X_{4}+\beta_{5} \ln X_{5}+\beta_{6} \ln X_{6}+\beta_{7} \ln X_{7}+$ $\beta_{8} X_{8}++\beta_{9} X_{9}+\beta_{10} X_{10}+\beta_{11} X_{11}+\left(v_{i}-u_{i}\right)$

Description:

$\mathrm{Y} \quad=$ Production of garlic $(\mathrm{Kg})$

$\alpha=$ Intercept

$\beta_{1}-\beta_{11}=$ Regression coefficient

$\mathrm{X}_{1}=$ land area $(\mathrm{Ha})$

$\mathrm{X}_{2} \quad=$ garlic seed $(\mathrm{Kg})$

$\mathrm{X}_{3}=$ organic fertilizer $(\mathrm{Kg})$

$X_{4}=$ NPK fertilizer $(\mathrm{Kg})$

$X_{5}=$ Zk fertilizer $(\mathrm{Kg})$

$X_{6}=$ Za fertilizer $(\mathrm{Kg})$

$\mathrm{X}_{7}=$ SP36 fertilizer $(\mathrm{Kg})$

$\mathrm{X}_{8} \quad=$ pesticide (Liter)

$\mathrm{X}_{9} \quad=$ biological agent (Liter)

$\mathrm{X}_{10}=$ labor (HOK)

$\mathrm{X}_{11}=$ the level of SOP implementation (score)

vi $=$ Random error which assumed as independently and identically distributed $\mathrm{N}\left(0, \sigma_{v}^{2}\right)$,

ui $=$ The effect of technical inefficiency (error that can be managed by farmers)

In order to determine the distribution parameter value (ui) of technical inefficiency of garlic farming, the formulation described below was used. 
$u_{i}=\delta_{0}+\delta_{1} Z_{1}+\delta_{2} Z_{2}+\delta_{3} Z_{3}+\delta_{4} Z_{4}$

In which

$u_{i}=$ Technical inefficiency value

$\delta i=$ Constanta

$Z_{1}=$ Farmers' age

$Z_{2}=$ Dummy of participation in farmer group

$Z_{3}=$ Formal education level (years)

$Z_{4}=$ The number of family members in productive age

The applied parameter sign is $\delta 1>0 \delta 2, \delta 3, \delta 4<0$.

The analysis of technical efficiency and technical inefficiency are simultaneously performed through Frontier 4.1 computer program. If the inefficiency estimator parameter is negative, the variable could decrease the inefficiency of ran business. However, if the inefficiency estimator parameter is positive, the variable will have positive influences towards the increasing business inefficiency or decreasing the business inefficiency level. The analysis results will also provide variance estimation values in the form of parameterization (Coelli et al., 2005).

$\sigma^{2}=\sigma v^{2}+\sigma u^{2}$

$\gamma=\sigma u^{2} / \sigma^{2}$

In which $\sigma^{2}$ is a total variance of error term and $\gamma$ is the gamma. Variance parameter can be used to acquire $\gamma$ value, therefore, $0 \leq \gamma \leq 1$. The $\gamma$ parameter value is the contribution of technical efficiency of the entire effects. The gamma value approaching 0 shows that the entire error terms included in the production function model are derived from noise factor, while if the gamma value approaching 1 shows that the error term is only derived from the inefficiency effect (Trujillo \& Iglesias, 2013).

\section{RESULTS AND DISCUSSION}

The technical efficiency analysis of garlic farming

Technical efficiency reflects the capability of farmers to acquire maximum output from certain amount of input. The technical efficiency value is the ratio between the actual production and the potential production. This research used the stochastic frontier production function as a basis to calculate the production efficiency of garlic and discover the factors influencing the production inefficiency.

The results of the analysis of stochastic frontier production model of garlic farming in Temanggung Regency is presented in Table 1. (1) The land area variable (X1) has significant influence at $1 \%$ level of $\alpha$. The average land tenure of farmers for garlic farming is around 0.3 ha. Heryono et al., (2016) tated that the larger the land area, the higher production will be through greater farming technology utilization. (2) The garlic seeds variable (X2) has significant influence at $1 \%$ level of $\alpha$. The common garlic seeds planted in 
the research location are Lumbu kuning and lumbu hijau varieties. The farmers can produce their own garlic seeds from the previous harvest. The more seeds that are used, the more crops (garlic) that can be planted (Banyuriatiga et al., 2017). (3) The ZK fertilizer variable (X5) has significant influence at $5 \%$ level of $\alpha$.

ZK fertilizer containing potassium $(\mathrm{K})$ is useful for tuber filling and $\mathrm{pH}$ neutralization. Garlic farmers use this fertilizer as additional fertilizer even though it is not recommended in GAPSOP. Potassium (K) can already be met from NPK fertilizer, so using ZK fertilizer causes excess potassium (K). (4) The pesticide variable (X8) has significant influence at
$10 \%$ level of $\alpha$. The most widely used pesticides are fungicides containing plant growth regulator. The application of these pesticides is useful for controlling fungi and spurring plant growth. (5) The adoption level of GAP-SOP variable (X12) has significant influence at $1 \%$ level of $\alpha$. The cultivation technology listed in the GAP-SOP has not been fully implemented by farmers. It is caused by the implementation of GAP-SOP of garlic which has been introduced since 2016. In other words, garlic farmers are still trying to apply this technology. Beside that, they have not been able to completely switchover from conventional cultivation that has been done for more than 10 years. The technological adoption in agricultural

Table 1. The Analysis Results of Stochastic Frontier Production Function on the Agribusiness of Garlic in Temanggung Regency

\begin{tabular}{lcrrc}
\hline Variables & Parameter & \multicolumn{1}{c}{ Coefficients } & \multicolumn{1}{c}{ t-ratio } & Information \\
\hline Constants & $\beta_{\mathrm{o}}$ & -1.0908 & -0.9061 & $\mathrm{Ns}$ \\
Land area & $\beta_{1}$ & 0.5689 & 3.2402 & $* * *$ \\
Seed & $\beta_{2}$ & 0.3194 & 3.0012 & $* * *$ \\
Organic Fertilizer & $\beta_{3}$ & 0.0017 & 0.0730 & $\mathrm{Ns}$ \\
NPK Fertilizer & $\beta_{4}$ & -0.0121 & -1.1451 & $\mathrm{Ns}$ \\
ZK fertilizer & $\beta_{5}$ & -0.0211 & -1.3232 & $* *$ \\
ZA fertilizer & $\beta_{6}$ & -0.0033 & -0.4226 & $\mathrm{Ns}$ \\
SP36 fertilizer & $\beta_{7}$ & -0.0015 & -0.1880 & $\mathrm{Ns}$ \\
Pesticide & $\beta_{8}$ & 0.1596 & 1.6194 & $*$ \\
Biological agent & $\beta_{9}$ & -0.0181 & -0.9719 & $\mathrm{Ns}$ \\
Labor & $\beta_{11}$ & -0.0936 & -0.7684 & $\mathrm{Ns}$ \\
Level of GAP-SOP & $\beta_{12}$ & 1.7151 & 5.1811 & $* * *$ \\
\hline Sigma square & & 0.2081 & 5.2461 & $* * *$ \\
Gamma & & 0.5487 & 3.3381 & $* * *$ \\
LR test of the one = sided error & & & & 14.49 \\
\hline
\end{tabular}

Source: Primary Data Analysis (2018)

Information:

* = Significantly influencing at $10 \%$ of $\alpha(1.2994)$

$* * \quad=$ Significantly influencing at $5 \%$ of $\alpha(1.67722)$

$* * *=$ Significantly influencing at $1 \%$ of $\alpha(2.40658)$

ns $=$ not significant 
cultivation is capable of increasing crops productivity and farmers' income (Hasan \& Roswita, 2013).

Table 1 also describes the variance value or sigma-square $\left(\Sigma^{2}\right)$ and gamma parameter $(\gamma)$ of technical inefficiency effect on the garlic farming. The sigma square value is 0.2081 , categorized as small value (approaching 0 ) and significant at $1 \% \alpha$ level. Therefore, the value is normally distributed. It means that the production variety of garlic contributed by the inefficiency and external effects have the actual variation. The gamma value approaching to $1(0.548)$. It shows that $55 \%$ of error terms are caused by the inefficiency effect, while the remaining $45 \%$ are caused by the external factors (noise) such as climate, pests and diseases, etc. These conditions are also shown by the LR test which resulted in 14.49 values. This value is bigger than the value of Kodde and Palam at $2.5 \%$ level of $\alpha$ (13.742). It can be concluded that garlic production in Temanggung Regency is influenced by both the technical efficiency and inefficiency. Factors affecting technical inefficiency are shown in Table 2.
The estimation results of inefficiency effect model are shown in Table 2. The farmer age variable (Z1) and the number of labor in the family variable (Z4) have a positive value with significant influence at $5 \%$ and $1 \%$ respectively. It means that the older the age of farmer and the bigger number of labor in the family will increase the inefficiency or decrease the technical efficiency level. While the participation in farmer group variable (Z2) and farmer education variable (Z3) have a negative value with significant influence at $1 \%$.

It means that higher education of farmer and the participation in farmer group will reduce the inefficiency effect or increase the technical efficiency on garlic farming.

The variable of farmer age (Z1) has a positive influence on the technical inefficiency level in which the addition of farmer age will make farming into less efficient. The average age of garlic farmers is 42 years old. The youngest farmer's age is 23 years old while the oldest age is 96 years old. As many as $40 \%$ of respondents are in the age range 41-60 years old. At that age range, the performance, skills

Table 2. The Analysis Result of Factors Affecting Technical Inefficiency

\begin{tabular}{lcrrc}
\hline \multicolumn{1}{c}{ Variables } & Parameter & Coefficients & \multicolumn{1}{c}{ t-ratio } & Information \\
\hline Constants & $\mathrm{Z}_{0}$ & 0.4334 & 0.8105 & Ns \\
Age & $\mathrm{Z}_{1}$ & 0.0128 & 1.7699 & $* *$ \\
Dummy of farmer group & $\mathrm{Z}_{2}$ & -0.8477 & -2.3835 & $* * *$ \\
Education & $\mathrm{Z}_{3}$ & -0.2378 & -4.9342 & $* * *$ \\
Labor in the family & $\mathrm{Z}_{4}$ & 0.3624 & 4.7598 & $* * *$ \\
\hline
\end{tabular}

Source: Primary Data Analysis (2018) 
and physical strength began to decline. This result is in line with the research of Ardiansyah et al.(2018) stating that the ability to work and the desire to bear the risk of declining over the time and as a result have an impact on increasing inefficiency. The variable of the number of labor in the family (Z4) is positively influencing the technical inefficiency level. More labor involved in a family makes the garlic farming to become inefficient. This condition is caused by garlic farmers in the research location who have been using agricultural machine and technology which are able to minimize the number of labor required. Most of garlic farmers in Kledung district already use electric sprayer to apply fertilizer, biological agent, and pesticide. In addition, most of the farmers have also employed mulch and the growth of weeds. Therefore, the involvement of labor in a family should be minimized.

The next variable is farmer participation in the farmer group (Z2). This variable is constructed in the form of dummy consisting of two categories: farmers participating in farmer group and the farmers who are not the member of the farmer group. The analysis results show that the variable of farmer group is significant with negative coefficient sign. It means that the farmers involved in the farmer group could decrease the technical inefficiency. This condition emerged as they acquire facilitation regarding the cultivation of garlic which in accordance with the standard operational procedure. In addition, the farmer group has become the media of exchanging information between farmers, facilitators and agriculture practitioners associated with the cultivation technology or the problems being faced in order to find a mutual solution. This is line with research Fadwiwati et al. (2014) stating that the dummy of participation in the farmer group is able to significantly decrease inefficiency on corn agribusiness. Ainembabazi et al. (2017) stated that strengthening farmer group is an important mechanism for improving farm productivity through reduced technical inefficiency in the input use.

The variable of farmer education level (Z3) affects the technical inefficiency significantly with a negative coefficient sign. It means that a higher formal education of farmers will decrease the technical inefficiency level. Farmers with high education will be more open in receiving information and having more ease in accepting the change of technology. Therefore, it could improve the inefficiency level.

Tahir et al., 2010 mentioned that the farmers with education tend to be more rational in the agribusiness. Most of garlic farmers in the research area are elementary school graduates which is about $56,67 \%$. Despite this condition, they have high willingness to develop their farming 
Table 3. The Distribution Frequency of Technical Efficiency of Garlic Farmers in Temanggung Regency

\begin{tabular}{ccc}
\hline $\begin{array}{c}\text { Distribution of } \\
\text { Index }\end{array}$ & $\begin{array}{c}\text { Number of } \\
\text { farmer }\end{array}$ & Percentage \\
\hline$<0.30$ & 1 & 1.7 \\
$0.31-0.40$ & 2 & 3.3 \\
$0.41-0.50$ & 3 & 5.0 \\
$0.51-0.60$ & 3 & 5.0 \\
$0.61-0.70$ & 5 & 8.3 \\
$0.71-0.80$ & 3 & 5.0 \\
$0.81-0.90$ & 15 & 25.0 \\
$0.91-1.00$ & 28 & 46.7 \\
\hline Total & 60 & 100 \\
Average & 0.811 & \\
Minimum & 0.287 & \\
Maximum & 0.962 & \\
\hline
\end{tabular}

Source: Primary Data Analysis (2018)

by participating in various training on garlic farming in the form of non-formal education. As a result, it enables them to acquire skills in enhancing the production and efficiency rate.

According to the results of technical efficiency of each respondent in Table 3, it can be seen that the average level of technical efficiency of overall respondents in Temanggung Regency is 0.811 with 0.962 as the highest value and 0.287 as the lowest. This result is supported by Sriyadi (2010) stating that garlic farming in Karanganyar Regency is efficient. In that order, the respondents in average have reached technical efficiency in the production of garlic. Thus, it is not necessary for them to increase the production input although it is one of factors affecting the crops directly. However, farmers have to consider the other factors influencing technical efficiency. On a short times basis, the garlic farmers in average have the opportunity to increase the yield by $15.7 \%(1-(0.811 / 0.962))$ by applying the production input, skills and cultivation technology as efficient as possible. According to the estimation results of parameter on the production function, the significant and positively influencing variables toward inputs on the production are land width, seed, pesticide and the implementation level of SOP. It means that if the entire inputs are used and the implementation of SOP is increased, garlic production could be improved.

\section{CONCLUSION AND SUGGESTION}

The production factors such as land area, garlic seed, ZK fertilizer, pesticide and the level of application of garlic GAP-SOP have positive and significant effect on garlic production. The average technical efficiency level of garlic farming in Temanggung Regency is 0.811 which is categorized as efficient. The level of GAP-SOP implementation has an actual influence towards the improvement of garlic production. In addition, the low productivity of garlic in Temanggung Regency is influenced by the technical inefficiency. The social economy factors influencing the technical inefficiency are age, farmer group, education and the number of labor in the family. Since the level of GAP-SOP implementation becomes the most influential factor in increasing garlic 
production and its technical efficiency, garlic farmer has to follow the GAP-SOP as recommended. In addition, it is also needed to increase technical efficiency of garlic farming by integrating the contribution of farmer group to provide a facility to access information and counseling about the application of GAP-SOP, so that farmer's skill and knowledge in garlic farming can be developed comprehensively. The average age of garlic farmers is categorized as productive age, but the level of formal education is relatively low. This condition causes the cultivation of garlic is not optimal. Therefore, farmers need to take part in non-formal education such as field schools or training related to garlic cultivation. Furthermore, it can improve farmers' skills, so as to increase production and efficiency rate.

\section{REFERENCES}

Adrianto, J., \& Parulian Hutagaol, dan M. P. H. (2016). Peningkatan Produksi Padi Melalui Penerapan SRI (System of Rice Intensification) Di Kabupaten Solok Selatan. Jurnal Agribisnis Indonesia, 4(2), 107-122.

Ainembabazi, J. H., van Asten, P., Vanlauwe, B., Ouma, E., Blomme, G., Birachi, E. A., ... Manyong, V. M. (2017). Improving the speed of adoption of agricultural technologies and farm performance through farmer groups: evidence from the Great Lakes region of Africa. Jurnal Agricultural Economics, 48(2), 241-259. https://doi.org/10.1111/ agec. 12329

Ardiansyah, N., Hartono, S., \& Suryantini, A. (2018). Technical Efficiency of Soybean in Pandeglang Regency. Agro Ekonomi, 29(1), 1-17. https:// doi.org/http://doi.org/10.22146/ ae.29839

Banyuriatiga, Darwanto, D. H., \& Waluyati, L. R. (2017). Production Efficiency of Seaweed Farming in Tarakan North Borneo. Agro Ekonomi, 28(1), 80-94.

Coelli, T., Rao, D. S. P., \& Battese, G. E. (2005). An Introduction to Efficiency and Productivity Analysis (second edi). Boston, MA: Springer US. https://doi.org/10.1007/978-1-46155493-6

Fadwiwati, A. Y., Hartoyo, S., Kuncoro, S. U., \& Rusastra, I. W. (2014). Analyses of Technical, Allocative , and Economic Efficiencies of Maize Farm Management by Variety in Gorontalo Province. Jurnal Agro Ekonomi, 32(1), 1-12. https://doi. org/http://dx.doi.org/10.21082/jae. v32n1.2014.1-12 
Falo, M., Juan, S., Norawati, A., \& Kapitan, O. (2016). Faktor-Faktor yang Mempengaruhi Produksi dan Strategi Pengembangan Usahatani Bawang Putih di Kecamatan Miomaffo Barat Kabupaten Timor Tengah Utara. Jurnal Agrimor, 1(4), 84-87.

Hariwibowo, P. A., Anindita, R., \& Suhartini. (2014). Permintaan bawang putih di Indonesia. Jurnal Habitat, 25(2), 93-98.

Hasan, N., \& Roswita, R. (2013). Jurnal teknologi pertanian. Jurnal Teknologi Pertanian, 8(2), 75-82.

Heryono, M., Nugroho, I., \& Hanafie, R. (2016). Analysis of Efficiency on Rice Farming. Agricultural Socio-Economics Journal, 16(1), 31-37. https://doi.org/10.6084/ m9.figshare.6265214

Nainggolan, S., Amir, A., Napitupulu, D. M. T., \& Delis, A. (2017). Research Article Estimation of Efficiency And Risk Behaviors Productivity For Rice Farmers in The Province of Jambi. Asian Journal of Science and Technology, 08(03), 4507-4516.

Sriyadi. (2010). Risiko Produksi dan Keefisienan Relatif Usahatani
Bawang Putih di Kabupaten Karanganyar. Jurnal Pembangunan Pedesaan, 10(2), 69-76.

Tahir, A. G., Darwanto, D. H., Mulyo, J. H., \& J. (2010). Production Efficiency Analysis of Soybean Farming System in South Sulawesi. Agro Ekonomi, 28(2), 133-151.

Taraka, K., Sidique, S. bin A., Latif, I. A., \& Shamsudin, M. N. (2011). Estimation of Technical Efficiency for Rice Farms in Central Thailand Using Stochastic Frontier Approach. Asian Journal of Agriculture and Development, 9(2), 1-10.

Trujillo, J. C., \& Iglesias, W. J. (2013). Measurement of the technical efficiency of small pineapple farmers in Santander, Colombia: a stochastic frontier approach. Revista de Economia e Sociologia Rural, 51(suppl 1), s049-s062. https://doi.org/10.1590/S010320032013000600003

Zelelew, D. Z., Kidane, T. T., \& K, A. S. (2017). Potentials and Constraints of Garlic Production in Southern Region, Eritrea. ARPN Journal of Agricultural and Biological Sciences, 12(8), 249-257. https:// doi.org/ISSN 1990-6145 